Anatolian Journal of Education

$2016 \bullet$ Vol.1, No.1

e-ISSN: 2547-9652 • www.e-aje.net

\title{
Classroom Management Challenges: An Account of EFL Teachers at Private Language Institutes
}

\author{
Neda Soleimani \\ Shiraz University, Shiraz, Iran, Soleimani_neda92@yahoo.com \\ Ayatollah Razmjoo \\ Shiraz University, Shiraz, Iran, arazmjoo@rose.shirazu.ac.ir
}

\begin{abstract}
Classroom management is one of the most contributing yet challenging issues in a teaching career. In a language-learning classroom where foreign language is used as both the medium and the content of the teaching, EFL teachers may experience unique classroom management challenges (Linse\& Nunan, 2005). This basic qualitative study focused on the main types the management challenges that EFL teachers face in their classroom and the strategies used to survive these challenges. To this end, the researchers selected 30 EFL teachers working at private language institutes in Shiraz, Iran and conducted semi-structured interviews to collect the data. Theme analyses showed three major themes in classroom management challenges: (1) instructional challenges (2) behavioral and psychological challenges and (3) contextual challenges. Instructional challenges were pertinent to the unfinished homework assignments, inconsistency in learners' level of proficiency and the learners' insistence on speaking in their first language. Behavioral and psychological challenges were related to the learners' unwillingness to speak, demotivate, naughty learners, latecomers and inappropriate use of cellphone and apps. To survive these challenges, EFL teachers suggested different strategies including warning, eye contact, teacher-leaner conference, etc. The implications, limitations and suggestion for future studies were discussed in more details in the paper.
\end{abstract}

Keywords: EFL teachers, classroom, management, challenges, private language institutes.

\section{INTRODUCTION}

Classroom management is a cardinal element defining a flourishing teaching career. Generally, classroom management encircles a wide range of steps and activities to establish a welcoming atmosphere of learning, ensure smooth running of lessons, and minimize the misbehaviors and disruptions (Raizen, 2010; Oliver, Wehby \& Reschly, 2011). According to Martin and Sass's (2010) theoretical framework, teachers' preventive strategies to control misbehaviors pertain to behavior management and selecting materials, setting daily rules and regulations refer to instructional management (Martin \& Sass, 2010).

Citation: Soleimani N., \& Razmjoo, A. (2016). Classroom Management Challenges: An Account of EFL Teachers at Private Language Institutes. Anatolian Journal of Education, 1(1), 51-69. https://doi.org/10.29333/aje.2016.114a

**Corresponding author. 
Martin and Yin (1997) asserted that managing classroom varies depending on the number of factors including subject matter, place of teaching and level of education. As such, managing language learning classrooms is expected to be dissimilar from managing math, history and geography classes. English as foreign language (EFL) classroom management demands certain skills and capabilities the most important of which is using English to manage classroom (Ababneh, 2012). In a more comprehensive definition, Richards, Platt, Platt and Heidi (1992) portrayed language classroom management as:

"The ways in which student behavior, movement, interaction, etc., during a class is organized and controlled by the teacher to enable teaching to take place most effectively. Classroom management includes procedures for grouping students for different types of classroom activities, use of lesson plans, handling of equipment, aids, etc., and the direction and management of student behavior and activity".(p.52).

In another classification, Brown (2001) proposed that EFL classroom management encompasses handling physical setting including light, seating, and facilities in the classroom. In addition to all these aspects, Richards and Rodgers (2001) asserted that EFL classroom management requires teachers' control over students' behavior and teachers-students interactions. Given the significance of successful classroom management in teaching professions, teachers might resort to different tricks and techniques to generate a well-managed classroom. Organizing classrooms and building a stress-free environment where very little disruptive behaviors happen and learning is a pleasant experience, may be a serious concern for both experienced and novice teachers (Merc, 2004). This situation could be more complex when it comes to learning a foreign language (Fowler \& Sarapli, 2010). EFL classroom management entails its own challenges for most of the EFL teachers regardless of their level of teaching experience (Harmer, 2007). In support of this claim, Alam Khan (2011) referring to classroom management as a painstaking challenge for most EFL teachers in Saudi Arabia stressed that in EFL classrooms teachers are not just concerned with language teaching and offering correct guidelines for handling e-Learning makes EFL teachers' management process more demanding.

Although classroom management strategies and disciplines have been the focus of many lines of inquiry in general teacher education, the challenges of EFL classroom management needs more focal attention. Regarding the contribution of effective classroom management in maximizing the efficacy of teaching, it is necessary to understand the types of classroom management challenges that EFL teachers face and find solutions to remove them. Cognizant of this, the focus of this line of investigation is 
describing the main EFL classroom management challenges and the most practical remedies to solve these challenges at private language institutes.

\section{Review of the Key Studies}

Classroom management issues have been acknowledged as indispensable aspect of the classroom discourse studies (Doyle, 1986). In his review of literature into classroom management, Walter Doyle (1986) maintained that "Classroom teaching has two major task structures organized around the problems of (a) learning and (b) order" (p. 394). Inspired by this definition, classroom management and classroom discipline have been used interchangeably in some studies (Cited in Martin \&Sass, 2010). Classroom discipline refers to a collection of preventive activities to minimize misbehaviors and deviations and bears an authoritarian regime in class (Robertson, 1996), whereas classroom management is a broader term describing teachers' plans and decisions for learning materials, interactions with students, and other aspects related to time and space of the classroom (Evertson \& Weistein, 2006). Given that, classroom management involves teachers' efforts to create democracy in classroom and a positive atmosphere where students' right to share ideas and opinions are celebrated and effective learning is facilitated (Tuncay, 2010). Creating a well-managed learning environment could be an undeniably demanding task. The review of related studies showed that teachers face many diverse behavioral, instructional, and other marginal problems in their classroom management that slow down their teaching and cause dissatisfaction. Earlier studies showed that a noisy and chaotic environment has destructive effects on learners and classroom management challenges are evident in this type of settings (Kayıkçı, 2009).

In a taxonomy developed by Gower and Walters (1988), size of classroom, starting and finishing lessons and group works caused main classroom management challenges. Later on, in a more comprehensive study, McPhillimy (1996) added students' behavioral problems to the possible sources of classroom management challenges. He asserted that naughty students' rule breaking behaviors, asking permission to get out of the class, making noise, creating disruption and mess in the seating arrangement posed big classroom management challenges for most teachers.

In a qualitative study, Mau (1997) found that survival concerns, motivating students, and fulfilling students' needs were also classroom management challenges for student teachers in Singapore. Other similar studies gave credence to these findings about the types of the challenges of classroom management experienced by teachers (LaMaster, 2001; Valdez, Young \& Hicks, 2000).

Classroom management profiles and type of challenges attached to this issue differ across contexts and cultures (Martin \& Yin, 1997). Given that, types of classroom 
management challenges in an EFL context are assumed to be different from other classes. Using a foreign language in an EFL classroom has been voiced as a problem for most of beginning teachers and this challenge led into difficulties in controlling classroom (Melnick \& Meister, 2008). In a like manner, Prada and Zuleta (2005) asserted that switching the codes in EFL classroom might generate stress and discomfort in learners. To reduce this challenge they proposed that teachers use their first language to hinder confusion and minimize the anxiety.

Korukcu (1996) indicated that teaching methods, lesson planning and students' motivation were major sources of classroom management challenges for EFL teachers. Additionally, Brown (2001) explicated that size of the classroom, inconsistency of the proficiency level of the learners, and complying with the rules of schools and institutions were among the most recurrently faced challenges of EFL classroom management. Aydın and Bahçe (2001) conducted a study in Turkey and their findings illustrated that the most serious problems of managing EFL classroom were motivation of students and dealing with noise and time. In another study in Turkey, Merç (2004) classified these problems in a more comprehensive list: students' based problems, teacher-students problems, and contextual and supervisor problems. In a qualitative study, Merc and Subasi (2015) studied classroom management problems and coping strategies of Turkish student EFL teachers. They asked 12 students EFL teachers to keep diaries over 12 weeks describing their main classroom management challenges and then they conducted semi-structured interviews. Findings of that study showed that students' misbehaviors and selecting material of teaching were main challenges of classroom management. To remove the classroom management challenges, Turkish EFL mainly teachers used warning, silence and ignorance.

The other challenge of classroom management in EFL contexts has been the change of curriculum in most of Asian countries, which necessitated learner-centered approaches to teaching. This new orientation has exacerbated the job of teaching and managing classroom for some teachers holding a negative belief about learner-centered classes. Keiko Sakui (2007) investigated classroom management in Japanese EFL classrooms and findings of that study demonstrated that running communicative language teaching activities (CLT) in Japan generates problems in managing the classroom and EFL programs should take account of culture specific teacher training plans to alleviate these challenges. In congruence with this study, Carless (2009) asserted that in eastern contexts, directing pair and group works, which are common practices in EFL classrooms, were perceived as challenging posers in classroom management and implementing traditional teaching tasks and directing a teacher-fronted classroom were more favored. However, Kadir and Qadir (2012) maintained that reconsiderations in the curriculum and the tendency toward a learner-centered language teaching permitted 
some degree of latitude for the EFL teachers in considering learners' ideas and needs in selecting materials and handling class and classroom management challenges were much less than when teachers were the primary authority in the classroom. Overall, In EFL classes where learning to communicate is presumed to be of primary importance, sustaining a balance between traditional beliefs and learner-centeredness might impose some difficulties for EFL teachers (Kang, 2013).

Classroom management challenges due to the cultural backgrounds in EFL contexts have been the subject of some studies. In 2015, Zhou and Li concentrated on the cultural mismatches between learners and their American teachers. They found that cultural incongruences gave rise to clashes and challenges in classroom management.

In Iran, classroom management and discipline have been the backbones of studies pertinent to EFL. However, the focuses of these studies were the theoretical approaches to classroom management and very few study pinpointed the practical challenges in EFL classroom management. Rahimi and Assadollahi (2012) focused on EFL teachers' approaches to classroom management. They found that Iranian EFL teachers mainly resort to controlling classroom management approaches. In a more recent study, Yazdanmehr and Akbari (2015) indicated that leaners' misbehaviors were the most serious challenges in their classroom management and EFL expert teachers' body language and setting clear expectations reduce the challenges of classroom management and contribute to expert EFL teacher training. In another study, Rahimi and Hoseini Karkami (2015) showed that English teachers mainly encounter the challenge of sustaining balance in being an efficacious and caring teacher and reducing deviations and unacceptable behaviors in classroom. However, very little is known about classroom management challenges and how these challenges are tackled in the context of Iran. To address this inadequacy, this study focused on types of classroom management challenges and how EFL teachers face them. Regarding the attached significance to classroom management issues in a successful teaching career (Baker \& Westrup, 2000), delving into this point could enhance the efficacy of teaching and learning. However, comparing to the amount of studies into classroom management challenges in general education, scant attention has been paid to EFL classroom management challenges in the context of Iran. This study was an attempt to address classroom management challenges that EFL teachers experience and the strategies to minimize these challenges. More specifically put, the following research questions were raised:

1. What are the major EFL classroom management challenges?

2. What strategies do EFL teachers employ to confront these challenges? 


\section{METHOD}

This study is a basic qualitative/interpretive research. According to Ary, Jacobs, Sorensen, and Walkers (2010), "Basic qualitative studies, also called basic interpretative studies by some, provide rich descriptive accounts targeted to understanding a phenomenon, a process, or a particular point of view from the perspective of those involved" (p.453). In this study, the researchers intended to capture the challenges of managing a classroom from the EFL teachers' point of view and see what strategies might be effective in alleviating these challenges.

\section{Participants}

The population of this study is EFL teachers working at private language institutes in Shiraz. $30 \mathrm{EFL}$ teachers volunteered to participate in this study. The demographic information about participants of the study is represented in the following table (see table 1).

Table 1

Demographic Variables

\begin{tabular}{|c|c|c|c|c|c|c|c|c|}
\hline \multirow{2}{*}{$\begin{array}{l}\text { Demographic } \\
\text { features }\end{array}$} & \multicolumn{2}{|l|}{ Age } & \multicolumn{2}{|c|}{ Education } & \multicolumn{2}{|l|}{ Gender } & \multicolumn{2}{|c|}{$\begin{array}{l}\text { Teaching } \\
\text { experience }\end{array}$} \\
\hline & $<30$ & $>30$ & B.A. & M.A. & Female & Male & $\begin{array}{l}<5 \\
\text { years }\end{array}$ & $\begin{array}{l}>5 \\
\text { years }\end{array}$ \\
\hline Number & 12 & 18 & 17 & 13 & 18 & 12 & 11 & 19 \\
\hline
\end{tabular}

All of the interviewees were from Iran and taught English as a foreign language. They had the experience of teaching at different levels of proficiency.

\section{Instrument}

Semi-structure interviews were conducted to collect data. To develop the interview items and questions, review of literature and studies related to classroom management challenges were used. In a pilot study, interview questions were screened and double barreled and vague questions were eliminated from the questions and the focuses of interview questions were more clarified. To ensure the content validity of the interviews, member checking and peer checking were carried out. 


\section{Data Collection Analysis}

Before the interview sessions, the participants were informed about the purpose of the study and each interview session took about 15 minutes. To establish rapport with the participants, the interviews were conducted in Persian and then the tape-recorded interviews were transcribed. The following items were included in interview sessions:

a) A brief introduction of the participants and general background information

b) Inquiry about the main challenges of classroom management (specific and personal examples of their classroom)

c) Inquiry about how they solve the challenges of classroom management (what they do to minimize the challenges)

The researcher tried to elaborate the questions and asked the participants to explain their answers, however, it was attempted not to lead the responses. For example, it was tried not to ask double-barreled and or yes no questions. The interviews were continued up to data saturation point, which was the 23th interview, and then coding of the data was started. The researcher outlined the recurrent themes and sub-themes, which were expressed differently. The statements were checked for redundancy and clarity by two coders and the process of theme analyses was implemented up to the point that no new theme could be extracted (Charmaz, 2006).

\section{RESULTS AND DISCUSSION}

When the EFL teachers were asked about classroom management challenges, three major themes emerged. The researchers named these themes based on the review of literature and Wolfgang 's (2005) classroom management approaches. Therefore, the researchers named the themes as: a) instructional challenges, (b) behavioral and psychological challenges and (c) contextual challenges. Nearly all of the participants mentioned that they try to clarify their expectations with regard to the learners' behavior, instructional activities and other classroom related points to minimize the number of possible challenges. However, the participants asserted that some unexpected classroom management challenges were posed in approximately all EFL classrooms. To survive, EFL teachers might resort to different remedies. A summary of the most helpful and customary tips was displayed in the following tables.

\section{Instructional Challenges}

The first table shows five subthemes of the challenges related to instructional aspects. The majority of the participants contended that unfinished homework and take-home assignments were big challenges for them. Talking about this issue, an interviewee said: 
"Sometimes my students do not complete their homework assignments and this occasionally breaks my classroom routine. In addition, I believe that doing homework helps learners see if there is any problem with the lesson covered, so when the learners do not their homework, they might not have clear picture of their learning and performance".

Table 2

Instructional Challenges and Remedies

\section{Instructional related challenges}

a. Unfinished homework and take homeassignment
Remedies to address the challenges

1. warning and clarifying my expectations

2. informing the director of institute

3. assigning minus score

1. asking the director to administer a placement test again

2. asking the less proficient learners to study more and giving more challenging tasks to the more proficient ones

1. telling the learners about the importance of talking in English to learn the language first language

2. warning

3. ignoring

4. penalizing: e.g. buy snack or some drinks for the whole class d. Material selection and dealing with the syllabus

1. sticking to the syllabus of institute

2. suggesting further reading and secondary resources to the interested learners

e. Mismatch between teaching style and

1. using a simple example or language to learning outcomes

2. gestures and pantomime 
enjoyable tasks

Another participant alluded to unfinished homework as a problem leading to waste of time and slow rate of teaching. The lack of consistency in the level of learners' proficiency in the same classroom was another challenge for most of the teachers. More than half of the participants expressed that this challenge regularly resulted in confusion and dissatisfaction in teaching. The following comment illustrates this challenge:

"Unfortunately, I always have the problem of the lack of consistency in the proficiency level of the learners in the same classroom. This makes the teaching and task selection more challenging, as some tasks are easier for the learners at higher level of proficiency and the same tasks are really demanding for the learners at lower proficiency level".

As for the other challenge related to learners' insistence on talking in the first language instead of English, one of the interviewee explained that:

"In most of the language learning programs, the goal is improving speaking ability but some students resist speaking in English. Well! This is really frustrating and makes me feel that I have not been successful enough in my teaching".

Among other things, some learners expect their teachers to teach more than the contents of the book and present extra vocabulary and grammar structures. This piece of finding is in line with Mariam (2012) pointing to the difficulty of selecting material of teaching which caused challenges in classroom management for Pakistani English teachers. Sometimes, EFL learners have serious problems in adapting themselves with the teaching styles and their learning outcomes are not satisfactory. This challenge might be due to the complexity of language. In this case, EFL teachers said that they rely on simple instructions, body language and pantomime, picture and painting, and even shifting to the first language to help the learners understand the lesson.

Instructional activities and choosing appropriate styles of teaching constitute a considerably important part of a successful classroom management profile. EFL teachers in this study agreed upon the idea of using variety in teaching methods to upgrade the quality of classroom management. These results confirmed Demir (2009) who emphasized the importance of rich teaching activities in surmounting the challenges of classroom management. Additionally, Merç and Subaşı (2015), Kaya and Donmez (2009) suggested variation in teaching activities to optimize management outcomes.

\section{Behavioral and Psychological Challenges}

In comparison to instructional challenges, behavioral challenges were more context specific and individual. To address these challenges, EFL teachers devise their own 
strategy (see table 2).However the majority of EFL teachers complained that lack of punctuality and attendance were the most typically observed challenges. The following is one of EFL teacher' comment on this challenge:

"In most of the classes, there are always some latecomers. When they come, they make their usual excuses: I was stuck in the traffic jam, I could not take a taxi, I was very busy, etc. I try to be lenient at first and show my objection with facial expression and eye contact. But if this behavior is repeated I consider more serious reactions like sending the latecomers out to the principal's room".

Apart from this challenge, participants of this study described unwillingness to communicate as another annoying issue that causes some difficulties including the inefficacy of learning and creating a monotonous class. Maximizing leaners' willingness to communicate (WTC) is considered as one the strengths of EFL teachers' job. To this end, words of encouragement, explicit elaboration of speaking activities in language learning and versatility in speaking activities were suggested. Let us review some of the comments in this regard:

"In English learning classroom, the tendency of learners to communicate and initiate speaking means a lot and I do my best to motivate my learners to start talking. Sometimes I give them extra points to encourage them. Sometimes I say if you want to learn speaking you must speak and forget about being silent".

"I believe that error correction could have a great effect on learners' WTC. To ease the flow of speaking, I only interrupt my learners when they make global and remarkable mistakes. I think giving time to the learners for speaking help them increase self-confidence and WTC".

Table 3

Behavioral and Psychological Challenges and Remedies

\begin{tabular}{|c|c|}
\hline Behavioral and psychological challenges & Remedies to address the challenges \\
\hline a. latecomers & $\begin{array}{l}\text { b. warning } \\
\text { c. asking the learners to go to the office } \\
\text { and bring me a note justifying their } \\
\text { delay } \\
\text { d. not letting them in if the learner comes } \\
\text { late every session }\end{array}$ \\
\hline $\begin{array}{l}\text { b. unwilling to speak and } \\
\text { participate learners }\end{array}$ & $\begin{array}{l}\text { 1. encouraging the learners to talk } \\
2 \text { elaborating on the significance } \\
\text { of learning English in the } \\
\text { education and life } \\
\text { 3. deigning more enjoyable speaking } \\
\text { tasks and talking about interesting }\end{array}$ \\
\hline
\end{tabular}




\begin{tabular}{|c|c|}
\hline & $\begin{array}{l}\text { topics } \\
\text { 4. letting them talk and show less sever } \\
\text { reaction to their mistakes }\end{array}$ \\
\hline $\begin{array}{l}\text { c. demotivated and stressed } \\
\text { learners }\end{array}$ & $\begin{array}{l}\text { 1. creating a stress-free } \\
\text { environment: } \\
\text { 2. and treating learners in a } \\
\text { friendly manner }\end{array}$ \\
\hline d. noisy and naughty learners & $\begin{array}{l}\text { 1. talking to learner after class } \\
\text { 2. changing their seat } \\
\text { 3. ignoring them } \\
\text { 4. warning } \\
\text { 5. calling their names and ask them } \\
\text { question to catch their attention } \\
\text { 6. asking the learners to raise their hand } \\
\text { when they want to say something } \\
\text { 7. eye contact } \\
\text { 8. remaining silent }\end{array}$ \\
\hline $\begin{array}{l}\text { e. learners' use of cellphone and } \\
\text { apps }\end{array}$ & $\begin{array}{l}\text { 1. giving directions about appropriate use } \\
\text { of these facilities } \\
\text { 2. warning } \\
\text { 3. penalizing }\end{array}$ \\
\hline
\end{tabular}

The problem of noisy and naughty learners was another challenge. Although learners' enthusiasm for talking and class activity are considered as advantages of a successful language learning classroom, sometimes the class becomes much noisy and the learners might interrupt each other to talk or move around the class without permission. To solve this challenge, the participants of the study commented:

"To control noisy learners I use eye contact. When they are very talkative, I first look at them and I guess they understand me at that moment, if not I would call them and tell them I am really sorry to interrupt you".

This sarcastic utterance is a strategy to teach the learners acceptable behavior in a classroom (Colvin, Kame'enui \& Sugai, 1993).

Another interesting comment was: "When I see my learners talking and making noise, instead of shouting to I stop teaching and remain silent for a few minutes. This surprises them and attracts their notice. Sometimes, I keep silent and write "silence" on the board. In this way the learners come to understand and the get my message".

The emergence of new software and programs has revolutionized language education and created noticeable learning resource (Richards, 2014); however, inappropriate use of technology and apps could cause distractions in the classroom. Playing games, chatting online, checking websites and social networks, sending texts, and even checking dictionary were among the cases that result in deficit attention and disturbing thoughts. Here is an example of the comments in this regard: 
"These days most of the learners have smartphone and they can easily install many different software and apps on these phones. Some learners use e-books, listen to audio programs and use their cellphone to learn the language. However, some learners waste their time surfing through these apps and get busy with their cellphone during the class. These learners often do not concentrate on the lesson ".

To solve this challenge, most of the EFL teachers believed that they should raise the learners' consciousness about the opportunities provided by smartphones, apps and social networks to learn the language. However, sometimes, the learners ignore these chances and even miss the learning opportunities within the classroom. In that case, EFL teachers give the learners words of warning and in worse situations penalize the learners' inopportune cell phone and apps uses.

\section{Contextual Challenges}

The participants of this study asserted that sometimes a large number of the learners are cramped into a small room and this cause some troubles in terms of the physical distance and or the lack of enough space and seat for the learners. To withstand this challenge, the participants suggested that the supervisor of the institute divide the learners into two groups and or consider a bigger classroom for the leaners.

Table 4

Contextual Challenge and Remedies

\begin{tabular}{cl}
\hline \multicolumn{1}{c}{ Contextual challenges } & \multicolumn{1}{c}{ Remedies to address the challenges } \\
\hline a. busy classroom & 1. dividing the learners in two classrooms \\
\hline b. time management & $\begin{array}{l}\text { 1. skipping some marginal activities } \\
\text { 2. asking the learners to do some } \\
\text { activities at home }\end{array}$ \\
\hline
\end{tabular}

Mismanagement of the time was another serious challenge for the EFL teachers. The participants of the current study stated that sometimes they might fall behind their schedule ad not be able to move in accordance with their lesson plan and syllabus:

"I am teaching Topnotch series and the standard time to teach this book is about 60 hours. But I am supposed to finish it in 40 hours. So I have to focus on the main themes and skip some activities".

A much better recommendation to save the time and catch up with the syllabus would be observing the colleagues and asking for their tips. On a similar note, Chien (2014) considered observing experienced teachers as an effective way of developing teaching skills and time management. 


\section{CONCLUSION}

Results of the study revealed that EFL teachers mostly faced teaching related challenges, learners' off-task behaviors and some other problems with time and place of the classroom. To resolve these challenges, EFL teachers suggested different reactive strategies that vary depending on the contexts and the level of learners. Although the current study was based on a small sample of participants, it might carry some practical implications for language education as a whole. Studying about the types of challenges related to classroom management could raise the EFL teachers' awareness about this issue, contribute to self-reflection in teaching and finally enhance teaching (Kizildag, 2007). As pointed earlier, classroom management challenges are context bounded and approaches to minimize and or resolve these challenges also vary across individuals and educational systems. However, a picture of the common challenges experienced by EFL teachers at one specific institute could provide rich insights for novice teachers. Being more concerned with the instructional dimension, novice and pre-service EFL teachers might find coping with the unexpected challenges overwhelming. Thus, findings of this study could help them have a more realistic understanding of the classroom dynamics. Another implication of this study is that teacher trainer and teacher educators could refer to the tips and hints provided by the EFL teachers in terms of solving classroom management challenges in their teacher training programs. As Tal (2010) argued classroom management abilities are part of teaching qualities. EFL teachers need to know about the practical aspects of classroom management rather than the theoretical background to be able to handle their classroom and achieve their desired goal.

\section{Limitations of the Study}

This study is subject to some limitations. The researchers only focused on the private language institutes in which small number of participants was selected and interview was the only instrument used to collect the data. If we were to conduct this study again, we would use observation as another data collection instrument to back up the evidence obtained through the interviews and maximize the validity of the study. Seeking the views of learners, the principals of the language institutes and even parents could result in more illuminating aspects of a well-managed classroom and strategies to be implemented to alleviate the challenges. Further research should be undertaken in other language learning contexts (e.g. high school and university) to study whether the challenges are the same and what resorts are taken to figure out classroom management challenges. Studies into the impact of the learners' cultural background and demographic features on EFL classroom management challenges could yield interesting findings. 
EFL Teachers at Private Language Institutes

\section{REFERENCES}

Ababneh, S. (2012). Towards a Better English Classroom: Implementing Effective Classroom Management Strategies. International Journal of Education, 4(4), 300-312.

Alam Khan, I. (2011). Challenges of Teaching/Learning English and Management, Global Journal of Human social science, 11 (8), 69-85.

Ary D, Jacobs L, Sorensen C, \& Razavieh, A. (2010). Introduction to research in education (10th ed.). Canada: Wadsworth Publishing.

Aydın, B, \& Bahçe, A. (2001). Cases from STs. Paper presented at the International ELT Conference-2001 on "Searching for Quality in ELT". Eastern Mediterranean University, Gazimagusa

Baker, J., \& Westrup, H. (2000). The English language teacher's handbook. London: Continuum.

Brown, H. D. (2001). Teaching by Principles: An interactive Approach to Language Pedagogy (2nd ed). White Plains, NY: Longman

Carless, D. (2009). Revisiting the TBLT versus P-P-P debate: Voices from Hong Kong. Asian Journal of English Language Teaching, 19, 49-66.

Charmaz, K. (2006). Constructing grounded theory: A practical guide through qualitative analysis. London: Sage.

Chien, C. W. (2014. Pre-service English teachers' perceptions and practice of field experience and professional learning from expert teachers' mentoring. Teachers and Teaching: theory and practice, doi: 10.1080/13540602.2014.953817

Colvin G, Kame'enui E J, \& Sugai, G. (1993). Reconceptualizing behavior management and school-wide discipline in general education. Education and Treatment of Children 16: 361-381.

Demir, S. (2009). Teacher perceptions of classroom management and problematic behaviors in primary schools. Procedia Social and Behavioral Sciences, 1,584-589.

Doyle, W. (1986). Classroom organization and management. In Wittrock, M. C. (Ed.), Handbook of research on teaching (pp. 392- 431). New York: MacMillan.

Evertson, C. M, \& Weistein, C. S. (2006). Classroom management as a field of inquiry. In C. M. Evertson, C. S. Weinstein's (Eds.), Handbook of classroom management: Research, practice, and contemporary issues (pp. 3e15). Mahwah, NJ: Lawrence Erlbaum Associates. 
Fowler, J., \& Şaraplı, O. (2010). Classroom management: What ELT students expect. Procedia Social and Behavioral Sciences, 3, 94-97.

Gower, R., \& Walters, S. (1988). Teaching practice handbook. Oxford: Heinemann.

Harmer, J. (2007). the practice of English Language teaching (4th ed). Pearson: Longman.

Jones, V. F., \& Jones, L S. (2012). Comprehensive classroom management, creating communities of support and solving problems (10th ed). Upper Saddle River, NJ:

Pearson.

Kang, D. M. (2013). EFL teachers' language use for classroom discipline: A look at complex interplay of variables. System, 41(1), 149-163.

Kayıkçı, K. (2009). The effect of classroom management skills of elementary school teachers on undesirable discipline behavior of students. Procedia Social and Behavioral Sciences, 1, 1215-1225.

Kaya, A,. \& Dönmez, B. (2009). An evaluation of the classroom management approaches of the class teachers implementing constructivist learning approach. Procedia Social and Behavioral Sciences, 1, 575-583.

Kizildag, A. (2007). A longitudinal study on English language teachers' beliefs about disruptive behavior in classrooms: Case studies from practicum to the first-year in the profession. Doctoral Dissertation, Cukurova University, Adana, Turkey.

Korukcu, S. (1996). An analysis of the problems of beginning teachers to develop an induction program for the Basic English departments of Turkish Universities. (Unpublished Master's Thesis). Bilkent University, Ankara.

LaMaster, K. J. (2001). Exchanging pre-service teachers' field experiences through the addition of a service-learning component. Journal of Experiential Education, 24(1), 2733.

Linse, C., \& Nunan, D. (2005). Practical English language teaching. US: McGraw-Hill.

Martin, N. K., \& Sass, D. (2010). Construct Validation of the Behavior and Instructional Management Scale. Teaching and Teacher Education, 26(5), 1124-1135

Martin, N., \& Yin, Z. (1997). Attitudes and beliefs regarding classroom management style: Differences between male and female teachers. Paper presented at the 20th annual meeting of the Southwest Educational Research Association, Austin, TX (ERIC Document Reproduction Series No. ED 404738). 
Mariam, D. (2012). Banishing colonial specters: Language ideology and education policy in Pakistan. Working papers in educational linguistics, 1(27), 29-49.

Mau R. (1997) Concerns of STs: implications for improving the practicum. Asia-Pacific Journal of Teacher Education, 25(1): 53-65.

McPhillimy B (1996). Controlling your class. West Sussex: John Willey \& Sons Ltd.

Melnick, S. A., \& Meister, D. G. (2008). A comparison of beginning and experienced teachers' concerns. Educational Research Quarterly, 31(3), 39-56.

Merç, A. (2004). Reflections of pre-service teachers' throughout their teaching practicum: What has been good? What has gone wrong? What has changed? (Unpublished Master's Thesis). Anadolu University, Eskisehir.

Merç, A., \& Subaşı, G. (2015). Classroom Management Problems and Coping Strategies of Turkish Student EFL Teachers. Turkish Online Journal of Qualitative Inquiry, 6(1), 39-72.

Oliver, R. M., \& Wehby, J. H., \& Reschly, D. J. (2011). Teacher classroom management practices: effects on disruptive or aggressive student behavior. Campbell Systematic Reviews, doi:10.4073/csr.2011.4

Prada, L., \& Zuleta, X. (2005). Tasting Teaching Flavors: A Group of StudentsTeachers' Experiences the Practicum, PROFILE 6: 157-170

Raizen, E. (2010). Management, discipline and control. Retrieved from http://coerll.utexas.edu/methods/modules/classroom/01/

Rahimi, M., \& Asadollahi, F. (2012). On the relationship between Iranian EFL teachers' classroom management ordinations and teaching style. Procedia - Social and Behavioral Sciences, 31, 49-55.

Rahimi, M., \& Hosein Karkami, F. (2015). The role of teachers' classroom discipline in their teaching effectiveness and students' language learning motivation and achievement: A path method. Iranian Journal of Language teaching research, 3(1), 5782.

Richards, J.C. (2014). The Changing Face of Language Learning: Learning Beyond the Classroom. RELC Journal, 1 (18), 1-18.

Richards, J.C. \& Platt, J., \& Platt, H. (1992). Language Teaching and Applied Linguistics. London: Longman.

Richards, J. C., \& Rodgers, T. S. (2001), Approaches and Methods in Language Teaching (Second Edition). Cambridge: Cambridge University Press. 
Robertson, J. (1996). Effective classroom control. London: Hodder \& Stoughton

Sakui, K. (2007). Classroom management in Japanese EFL classrooms. JALT Journal, $29(1), 41-58$.

Tal, C. (2010). Case studies to deepen understanding and enhance classroom management skills in preschool teacher training. Early Childhood Edue Journal, $38,143-152$.

Tuncay, H. (2010). Class management in ELT: Who is the boss? Retrieved from http://hidayettuncay.com/makaleler/CLASS-MANAGEM-NT-IN-ELT.pdf.

Valdez, A., \& Young, B., \& Hicks, S. J. (2000) Preservice teachers' stories: content and context. Teacher Education Quarterly, 4, 39-57

Yazdanmehr, E., \& Akbari, R. (2015). an expert EFL teacher's class management. Iranian Journal of Language Teaching Research, 3 (2), 1-13

Zhou, W. Li. G. (2015). Chinese language teachers' expectations and perceptions of American students' behavior: Exploring the nexus of cultural differences and classroom management. System, 49, 17-27.

\section{EXTENDED ABSTRACT}

Classroom management is a cardinal element defining a flourishing teaching career. Generally, classroom management encircles a wide range of steps and activities to establish a welcoming atmosphere of learning, ensure smooth running of lessons, and minimize the misbehaviors and disruptions (Raizen, 2010; Oliver, Wehby \& Reschly, 2011). According to Martin and Sass's (2010) theoretical framework, teachers' preventive strategies to control misbehaviors pertain to behavior management and selecting materials, setting daily rules and regulations refer to instructional management (Martin \& Sass, 2010). Martin and Yin (1997) asserted that managing classroom varies depending on the number of factors including subject matter, place of teaching and level of education. As such, managing language learning classrooms is expected to be dissimilar from managing math, history and geography classes. English as foreign language (EFL) classroom management demands certain skills and capabilities the most important of which is using English to manage classroom (Ababneh, 2012). In a more comprehensive definition, Richards, Platt, Platt and Heidi (1992) portrayed language classroom management as:

"The ways in which student behavior, movement, interaction, etc., during a class is organized and controlled by the teacher to enable teaching to take place most 
effectively. Classroom management includes procedures for grouping students for different types of classroom activities, use of LESSON PLANS, handling of equipment, aids, etc., and the direction and management of student behavior and activity".(p.52). Although classroom management strategies and disciplines have been the focus of many lines of inquiry in general teacher education, the challenges of EFL classroom management needs more focal attention. Regarding the contribution of effective classroom management in maximizing the efficacy of teaching, it is necessary to understand the types of classroom management challenges that EFL teachers face and find solutions to remove them. Cognizant of this, the focus of this line of investigation is describing the main EFL classroom management challenges and the most practical remedies to solve these challenges at private language institutes. This study is a basic qualitative/interpretive research. According to Ary, Jacobs, Sorensen, and Walkers (2010), "Basic qualitative studies, also called basic interpretative studies by some, provide rich descriptive accounts targeted to understanding a phenomenon, a process, or a particular point of view from the perspective of those involved" (p.453). In this study, the researchers intended to capture the challenges of managing a classroom from the EFL teachers' point of view and see what strategies might be effective in alleviating these challenges. The population of this study is EFL teachers working at private language institutes in Shiraz. Purposive sampling method was used to select 30 participants. All of the interviewees were from Iran and taught English as a foreign language. They had the experience of teaching at different levels of proficiency. The analyses focused on the participants' major challenges in classroom management and available remedies to remove the challenges. The researchers compared the participants' answers to the questions and extracted the major themes and subthemes of the interviews. Depending on the age group of the learners, the type of offered textbooks, the atmosphere of the classroom and the institute, the expectations of learners about language learning the quality of learning program, the classroom management challenges vary for most of the EFL teachers. To survive, EFL teachers might resort to different remedies. A summary of the most helpful and customary tips was displayed in the following tables. The major themes of classroom management challenges were (a) instructional challenges, (b) behavioral and psychological challenges and (c) contextual challenges. The majority of the participants contended that unfinished homework and take-home assignments were big challenges for them. Instructional activities and choosing appropriate styles of teaching constitute a considerably important part of a successful classroom management profile. EFL teachers in this study agreed upon the idea of using variety in teaching methods to upgrade the quality of classroom management. In comparison to instructional challenges, behavioral challenges were more context specific and individual. To address these challenges, EFL teachers devise their own strategy (see table 2).However the majority of EFL teachers complained that 
lack of punctuality and attendance were the most typically observed challenges. The participants of this study asserted that sometimes a large number of the learners are cramped into a small room and this cause some troubles in terms of the physical distance and or the lack of enough space and seat for the learners. To withstand this challenge, the participants suggested that the supervisor of the institute divide the learners into two groups and or consider a bigger classroom for the leaners. This study is subject to some limitations. The researchers only focused on the private language institutes in which small number of participants was selected and interview was the only instrument used to collect the data. If we were to conduct this study again, we would use observation as another data collection instrument to back up the evidence obtained through the interviews and maximize the validity of the study. Seeking the views of learners, the principals of the language institutes and even parents could result in more illuminating aspects of a well-managed classroom and strategies to be implemented to alleviate the challenges. Further research should be undertaken in other language learning contexts (e.g. high school and university) to study whether the challenges are the same and what resorts are taken to figure out classroom management challenges. Studies into the impact of the learners' cultural background and demographic features on EFL classroom management challenges could yield interesting findings. 